\title{
Praksis Pendidikan Karakter dalam Novel Negeri 5 Menara Karya Ahmad Fuadi
}

\author{
Mashuri \\ SMA Negeri 1 Kauman Tulungagung \\ Perum Sobontoro Indah Blok H/2 Tulungagung. Email: hurimas@gmail.com
}

\begin{abstract}
The focus of this study are (1) the semiotic meaning of understanding virtues praxis by the characters, (2) the semiotic meaning of practical application of virtue by the characters, and (3) the semiotic meaning of reflection praxis on the actions taken by the characters. This study used a qualitative approach. Source of data is a text novel by Ahmad Fuadi N5M, thirteenth edition published in 2012. The research data analysis using Pierce semiotic analysis. Based on research data found as follows. (1) The semiotic meaning of understanding virtues praxis include seven things. (2) The semiotic meaning of practical application of virtue by the characters include the planting of five character value strategy. (3) The semiotic meaning of characters reflection praxis includes six new awareness.
\end{abstract}

Key Words: character education, comprehension activities, application activities, reflection activities, semiotic studies

\begin{abstract}
Abstrak: Fokus penelitian ini adalah (1) makna semiotik praksis pemahaman nilai-nilai kebajikan oleh tokoh cerita, (2) makna semiotik praksis penerapan nilai-nilai kebajikan oleh tokoh cerita, dan (3) makna semiotik praksis refleksi terhadap tindakan yang dilakukan oleh tokoh cerita. Penelitian ini menggunakan pendekatan kualitatif. Sumber data penelitian adalah teks novel N5M karya Ahmad Fuadi cetakan ketigabelas tahun 2012. Analisis data penelitian ini menggunakan analisis semiotik Pierce. Berdasarkan data penelitian ditemukan sebagai berikut. (1) Makna semiotik praksis pemahaman nilai-nilai kebajikan meliputi tujuh hal. (2) Makna semiotik praksis penerapan nilai-nilai kebajikan oleh tokoh cerita meliputi lima strategi penanaman nilai karakter. (3) Makna semiotik praksis refleksi tokoh cerita meliputi enam kesadaran baru.
\end{abstract}

Kata kunci: pendidikan karakter, aktivitas pemahaman, aktivitas penerapan, aktivitas refleksi, dan kajian semiotik

Pendidikan seharusnya tidak hanya membentuk insan Indonesia yang cerdas, tetapi juga berkepribadian atau berkarakter, sehingga akan lahir generasi bangsa yang tumbuh berkembang dengan karakter yang dijiwai nilai-nilai luhur bangsa serta agama. Kepribadian yang cerdas dan berkarakter (intelligence plus character) pada hakikatnya merupakan tujuan pendidikan yang sebenarnya. Karena itu, praksis pendidikan karakter di sekolah diharapkan dapat membentuk kepribadian siswa yang kuat yang memungkinkannya untuk mengembangkan potensi dirinya secara optimal sehingga menjadi generasi yang cerdas, berbudi luhur, dan berakhlak mulia.

Persoalan pendidikan karakter tersebut menjadi sumber inspirasi beberapa penulis novel seperti Andrea Herata dalam novelnya Tetralogi Laskar Pela- ngi (2005), Ahmad Fuadi dalam novelnya Negeri 5 Menara (2009), Akmal Nasery Basral dalam novelnya Anak Sejuta Bintang (2012). Secara eksplisit maupun implisit novel-novel tersebut mengangkat masalah-masalah pendidikan. Wacana pendidikan khususnya pendidikan karakter yang terungkap dalam karya sastra dapat dipandang sebagai hasil kesadaran kejiwaan masyarakat, sebagai sejarah mentalitas, sebagai cermin masyarakat, dokumen sosial budaya, serta sebagai sistem pemikiran, sistem pengetahuan yang dihadirkan dalam menangkap, memandang, dan memahami sebuah realitas (Lathief, 2010:v).

Hadirnya karya sastra ke ruang publik dapat dipandang sebagai tindak komunikasi atau gejala semiotik. Dalam hal ini teks sastra dipandang sebagai sistem tanda bermakna yang mengandung pesan ter- 
tentu kepada pembaca. Novel Negeri 5 Menara (N5M) baik secara eksplisit maupun implisit hendak menyampaikan pesan pendidikan kepada pembacanya. Novel tersebut menyajikan kisah perjuangan hidup anak manusia dalam mencapai cita-citanya saat menempuh pendidikan di sebuah pondok pesantren di Ponorogo, Jawa Timur. Alur kehidupan tokoh dalam novel tersebut dapat menjadi cermin bagaimana praksis pendidikan karakter yang dijalani seseorang sehingga memiliki kepribadian yang kuat dan sukses dalam meraih hal terbaik bagi dirinya.

Menurut Bohlin (1999:96) praksis pendidikan karakter adalah memupuk kebiasaan pikiran, hati, dan tindakan yang memungkinkan individu untuk berkembang, yaitu menggunakan waktu, bakat, dan energinya dengan baik agar dapat meraih yang terbaik bagi dirinya. Proses pembiasaan tersebut melibatkan aktivitas mental maupun fisik yang mencakup (1) fase kesadaran, yakni tumbuhnya kesamaan visi dalam suatu komunitas tentang pentingnya pengamalan nilainilai kebajikan tertentu demi kebaikan bersama, (2) fase pemahaman, yakni tumbuhnya pengakuan pada diri seseorang bahwa hidup saleh dan membuat pilihan yang bijak dapat memberikan kontribusi untuk kebahagiaan pribadi dan orang lain, (3) tumbuhnya aktivitas pembiasaan diri untuk selalu berbuat baik, yakni menempatkan nilai-nilai kebajikan dalam praktik kehidupan sehari-hari, (4) fase refleksi, yakni kegiatan berpikir untuk menilai apakah tindakan yang dilakukannya baik atau buruk dan apakah upaya yang dapat dilakukan di kemudian hari agar menjadi lebih baik.

Kajian semiotik terhadap novel $N 5 M$ sebagai subsistem budaya suatu masyarakat ditujukan untuk mendapatkan makna yang berharga atas karya tersebut bagi kehidupan khususnya tentang praksis pendidikan karakter yang dijalani tokoh cerita. Danesi dan Perron (1999:68-70) menyatakan bahwa tujuan utama semiotik adalah memahami kemampuan otak untuk memproduksi dan memahami tanda serta kegiatan membangun pengetahuan yang berharga tentang sesuatu dalam kehidupan manusia.

Guna mengungkap makna praksis pendidikan karakter dalam novel N5M digunakan teori semiotika Pierce. Berbeda dengan Saussure yang memandang tanda terdiri atas dua unsur yaitu signifier (signifiant) atau penanda dan signified (signifie) atau petanda, Pierce memandang tanda terdiri atas tiga unsur, yakni representamen, objek, dan interpretan. Representamen adalah bentuk tempat tanda itu ditempatkan; tidak harus berwujud materi, walaupun biasanya dia- sumsikan seperti itu, beberapa ahli menyebutnya piranti tanda (sign vehicle). Objek adalah sesuatu yang dirujuk oleh tanda tersebut. Adapun interpretan adalah pengertian atas tanda tersebut. (Chandler, 2007: 29). Konsep tanda Pierce ini disebut triadik karena memandang tanda terdiri atas tiga unsur yang merupakan satu kesatuan.

Lebih jauh Pierce menawarkan tipologi tanda yang merupakan akibat logis dari proses semiosis yang mengaitkan representamen dengan objek dan kemudian interpretannya. Jenis-jenis tanda dibedakan ke dalam tiga jenis, yakni ikon, indeks, dan simbol. Ikon adalah tanda yang menyerupai atau merupakan tiruan objek/interpretannya. Adapun kesamaan antara tanda dan objek/interpretan dapat meliputi aspek rupa, suara, rasa, bau, dsb. Contoh ikon adalah potret, kartun, efek suara dalam drama radio, dubbing suara pada soundtrack film, gambar tubuh (laki/ perempuan). Indeks adalah tanda yang berhubungan langsung dengan objek/interpretan baik hubungan secara fisik atau sebab akibat. Contoh indeks adalah (1) 'tanda alam’ seperti asap, guruh, jejak kaki, gema, (2) ‘gejala medis' seperti rasa sakit, ruam pada wajah, detak jantung, (3) 'alat ukur' seperti termometer, penunjuk arah angin, jam, dsb., (4) 'sinyal' seperti ketukan pintu, dering telepon, (5) 'rekaman’ seperti foto, film, video, rekaman suara, (6) ‘ciri seseorang' seperti tulisan tangan, lingkar badan. Adapun simbol adalah tanda yang tidak menyerupai objek/ interpretannya; bersifat arbitrer (manasuka), berdasarkan kesepakatan bersama. Misalnya jenis dan bentuk huruf suatu bahasa, tanda baca, lambang angka, kode morse, lampu lalu lintas, bendera suatu negara (Chandler, 2007:37).

Fokus penelitian adalah makna praksis pendidikan karakter dalam novel N5M yang mencakup (1) aktivitas pemahaman tokoh cerita terhadap nilai-nilai kebajikan baik secara ikonik, indeksikal maupun simbolik, (2) aktivitas penerapan nilai-nilai kebajikan oleh tokoh cerita baik secara ikonik, indeksikal maupun simbolik, dan (3) aktivitas refleksi tokoh cerita terhadap pengalaman menerapkan nilai-nilai kebajikan dalam kehidupannya baik secara ikonik, indeksikal, maupun simbolik.

\section{METODE}

Penelitian ini menggunakan pendekatan kualitatif karena lebih mengutamakan makna, penalaran, atau definisi suatu situasi/gejala dalam konteks tertentu. Penggunaan pendekatan tersebut bertolak dari 
asumsi bahwa realitas karya sastra harus dijelaskan sebagaimana esensi yang ada pada realitas itu sendiri. Dalam penelitian ini realitas karya sastra dipandang sebagai (1) gejala holistik, sehingga pemberian makna tidak dilakukan secara segmentatif, (2) wujud konkret karya sastra hanya merupakan pengejawantahan dari 'realitas $\mathrm{x}$-n' yang tidak identik dengan gejala objektifnya, (3) dalam menangkap 'realitas $\mathrm{x}$-n' peneliti harus mengadakan konkretisasi dan rekonstruksi melalui penafsiran, (4) nilai atau makna yang verstehen dalam karya sastra merupakan hal yang terpenting, dan (5) karya sastra merupakan totalitas yang tak dapat dilepaskan dari konteks, ruang, dan waktu (Aminudin, 1990:6).

Data dikumpulkan dengan teknik studi dokumentasi atau kajian kepustakaan disertai pemahaman secara mendalam terhadap representamen praksis pendidikan karakter yang terdapat dalam novel N5M. Kedalaman pemahaman tersebut dapat dicapai dengan membaca teks novel N5M secara berulang-ulang guna mengkonstruk praksis pendidikan karakter. Konstruk praksis pendidikan karakter ini sebagai panduan peneliti dalam menemukan representasi praksis pendidikan karakter dalam novel N5M.

Data dianalisis melalui kegiatan (1) pemberian kode data sesuai dengan fokus penelitian, (2) mengelompokkan data sesuai dengan fokus penelitian, (3) memaparkan data dan temuan yang meliputi aktivitas pemahaman, penerapan/pembiasaan, dan refleksi oleh tokoh novel secara deskriptif kualitatif, (4) menafsirkan dan memberi makna temuan dalam konteks praksis pendidikan karakter untuk memudahkan analisis data digunakan format analisis data yang mencakup (1) kode data, (2) jenis tanda, (3) makna PPK, (4) makna semiotik yang meliputi (i) firstness, (ii) secondness, (iii) thirdness.

\section{HASILDANPEMBAHASAN}

Temuan lambang verbal baik ikon, indeks, maupun simhol yang menandai aktivitas pemahaman tokoh cerita terhadap nilai-nilai karakter mengisyaratkan adanya pemahaman terhadap (1) pendekatan ibadah, (2) metode dan strategi pendidikan karakter, (3) konsep kedisiplinan, (4) konsep kesungguhan dalam berusaha, (5) konsep kepemimpinan, (6) pengaturan lingkungan belajar, (7) sumber nilai karakter.

Temuan lambang verbal baik ikon, indeks, maupun simbol yang menandai aktivitas penerapan nilainilai karakter oleh tokoh cerita mengisyaratkan adanya strategi pembiasaan yang meliputi (1) praksis kedisiplinan, (2) praksis kerja keras dan kesungguhan dalam berusaha, (3) praksis kepemimpinan, (4) praksis kebersamaan, dan (5) praksis ketaqwaan.

Temuan lambang verbal baik ikon, indeks, maupun simbol yang menandai aktivitas refleksi tokoh cerita terhadap nilai-nilai karakter mengisyaratkan tumbuhnya kesadaran tokoh cerita terhadap (1) manfaat praksis ibadah, (2) manfaat praksis kepemimpinan, (3) pentingnya mempunyai cita-cita/impian dan niat yang kuat, (4) tumbuhnya kedewasaan, (5) pentingnya hidup dalam suasana pergaulan yang baik, (6) kewibawaan dan ketinggian ilmu PM.

\section{Aktivitas Pemahaman Tokoh terhadap Nilai- nilai Karakter}

\section{Pendekatan Ibadah}

Pendekatan ibadah praksis pendidikan karakter dalam novel N5M ditandai dengan indeks (1) visi dan misi PM, (2) konsep menuntut ilmu dalam Islam, (3) pentingnya sikap sabar, (4) pentingnya berdoa untuk keberhasilan, (5) konsep hakikat hidup, dan (6) simbol keikhlasan pengabdian guru, serta (7) simbol peran agama dalam proses pendidikannya.

Ungkapan 'membentuk manusia mandiri yang tangguh' merupakan indeks visi PM dalam novel N5M. Ungkapan 'manusia mandiri' mengandung maksud bahwa PM ingin membentuk siswanya menjadi pribadi yang dewasa baik fisik, sosial, maupun spiritualnya. Ketangguhan pribadi siswa merujuk pada pengertian 'tidak mudah putus asa' atau tahan banting dalam menghadapi berbagai persoalan hidupnya. Kedewasaan dan ketangguhan para siswa tersebut diharapkan tidak hanya membawa kebaikan diri sendiri tetapi juga membawa keberkahan bagi dunia atau menjadi 'rahmatan lil alamin'. PM membekali para siswanya dengan ilmu umum dan ilmu agama seperti yang tercermin dari indeks misi yang diembannya.

Keberadaan visi dan misi lembaga pendidikan dalam konteks praksis pendidikan karakter sangat penting. Visi lembaga mengandung deskripsi karakter dasar lulusan yang akan dikembangkan sedangkan misi lembaga mengandung deskripsi bahan dan strategi yang ditempuh untuk mewujudkan visi lembaga. Karena itu, visi dan misi lembaga harus dipahami semua orang yang terlibat dalam proses pendidikan dan menjadi sumber inspirasi dalam menentukan program, pendekatan, dan strategi yang dipilih untuk mewujudkan visi tersebut. Tanpa visi yang jelas dan dipahami oleh semua pihak upaya pengembangan karak- 
ter di lembaga pendidikan akan menjadi sia-sia (Koesoema, 2007:156).

Penggunaan pendekatan ibadah juga ditandai dengan indeks konsep menuntut ilmu dalam Islam. Menuntut ilmu dalam Islam harus dilakukan dengan niat ikhlas hanya karena Allah SWT. Indeks keikhlasan guru dan siswa terungkap dengan penyataan ' $k a m i$ para ustad ikhlas mendidik kalian dan kalian ikhlaskan pula niat untuk mau dididik'. Pola hubungan ini mengisyaratkan pesan bahwa ikatan guru dan siswa dilandasi nilai-nilai ibadah, yakni aktivitas belajar dan mengajar dipandang sebagai aktivitas ibadah dengan harapan mendapat pahala (keridlaan) dari Allah SWT. Dalam mendidik, guru menempuh jalan amal yang dilandasi sikap ikhlas yang diungkapkan dengan simbol 'wakaf diri'. Ungkapan tersebut mengiaskan maksud guru menyerahkan jiwa dan raganya untuk kepentingan pondok/lembaga secara ikhlas. Pentingnya keikhlasan niat dalam segala amalan ibadah dijelaskan oleh para ahli agama bahwa segala perbuatan amal bergantung pada niatnya.

Implikasi dari pendekatan ibadah adalah adanya simbol yang mengiaskan peran agama dalam konteks praksis pendidikan karakter. Simbolisasi peran agama adalah menggunakan ungkapan 'agama adalah oksigen'. Oksigen sangat penting bagi kehidupan. Tidak ada satupun makhluk hidup di bumi yang tidak membutuhkan oksigen. Dapat dikatakan bahwa semua aktivitas pendidikan di PM harus berlandaskan nilai-nilai agama agar ilmu yang didapat membawa keberkahan bagi umat manusia.

\section{Metode dan Strategi Pendidikan Karakter}

Metode dan strategi praksis pendidikan karakter di PM ditandai dengan (1) ikon profil kiai, pemimpin pondok, dan profil guru, indeks (2) memadukan ilmu umum dan ilmu agama, (3) kegiatan pengembangan bakat dan minat siswa, (4) kebersamaan dalam belajar, (5) strategi guru dalam memotivasi siswa, (6) pendidikan akhlak, (7) kebersamaan guru dan siswa, dan (8) simbol kedalaman dan keluasan ilmu guru.

Penggunaan metode keteladanan ditandai dengan ikon profil kiai, pemimpin pondok dan profil guru. Kiai, pemimpin pondok digambarkan sebagai pribadi yang sangat berwibawa, memiliki suara yang dalam dan menenangkan. Adapun profil guru digambarkan berpenampilan energik, kreatif, pembelajar dan motivator yang hebat; pandangannya memancarkan aura bersahabat, dan mampu membagi energi positif kepada para siswanya. Kekayaan ilmu guru disimbolkan dengan ungkapan 'mata air ilmu'. Ungkapan tersebut mengiaskan maksud bahwa ilmu guru sangat luas dan dalam serta tidak akan habis walaupun tiap hari ditimba oleh ribuan siswanya.

Penyataan 'memadukan ilmu umum dan ilmu agama' seperti tercermin dari visi PM juga merupakan indeks strategi PM dalam praksis pendidikan karakternya. Terminologi ilmu umum dan ilmu agama merupakan tradisi keilmuan Barat. Ilmu umum merupakan akibat adanya pandangan Barat melalui filsafat positivistiknya yang beranggapan bahwa ilmu pengetahuan harus bisa diamati secara empiris. Ilmu agama yang bersumber dari wahyu Tuhan bagi ilmuwan Barat bukanlah ilmu yang bisa diukur sebagaimana ilmu umum. Karena itu, mereka membedakan antara ilmu umum yang bersumber dari fenomena alam dan kemasyarakatan yang dianggap benar dan ilmiah dengan ilmu agama yang bersumber dari keyakinan yang kebenarannya tidak bisa dikaji melalui verifikasi atau falsifikasi.

Kebersamaan belajar para siswa pada jam tambahan malam hari yang dipandu wali kelas merupakan indeks strategi PM dalam menumbuhkan nilainilai sosial, yakni sikap saling berbagi pengetahuan dan saling bantu dalam proses belajar. Wali kelas dapat memanfaatkan sebagian waktu yang ada untuk memberikan motivasi yang dapat memacu semangat belajar para siswanya. Pernyataan kiai, pemimpin pondok saat memberikan ucapan selamat kepada siswa yang berhasil naik ke kelas tertinggi, 'Mari kita bersyukur, kita telah diberi jalan oleh Tuhan untuk bersama melangkah sampai sejauh ini. Selamat atas naik ke kelas enam', merupakan indeks kebersamaan dalam proses pembelajaran.

Penggunaan kisah-kisah keteladanan dari berbagai buku merupakan indeks kreativitas guru dalam memotivasi siswanya. Guru membawa setumpuk buku ke dalam kelas dan membacakan potongan-potongan kisah yang ada di dalamnya dan mengulasnya sesuai dengan konteks kehidupan siswa. Strategi guru tersebut sangat tepat sebagai pendidikan karakter karena pendidikan karakter adalah pendidikan perilaku. Kisah-kisah keteladanan dari berbagai sumber merupakan bahan ajar yang sangat efektif bagi pendidikan karakter.

\section{Konsep Kedisiplinan}

Konsep kedisiplinan ditandai dengan $i k o n$ yang menggambarkan (1) profil petugas disiplin yang sangat keras, indeks yang mengisyaratkan (2) adanya konsekuensi aturan tanpa pandang bulu, (3) pemahaman aturan disiplin/ 'qanun', (4) fungsi 'qanun' atau aturan disiplin, (5) keteladanan siswa senior dalam kedisiplinan, (6) pentingnya sikap ikhlas dalam 
menerima hukuman, (7) fungsi metode jasus, dan (8) simbol yang melambangkan tegaknya aturan disiplin sebagai hal yang utama.

Keteraturan kegiatan keseharian yang ditunjang perilaku disiplin yang tinggi merupakan jaminan terselenggaranya proses pendidikan secara optimal. Aturan disiplin ditegakkan dengan keras. Keberadaan petugas disiplin dari siswa senior secara ikonis digambarkan memiliki perawakan pendek gempal seperti petinju Mike Tyson, berjas hitam, berkopiah, berselempang sajadah merah, irit komunikasi verbal, dan mudah menjatuhkan hukuman. Gambaran petugas penegak disiplin tersebut mengiaskan maksud kerasnya aturan disiplin ditegakkan. Tegaknya aturan disiplin merupakan jaminan atas keteraturan tata kehidupan di lingkungan sekolah yang memungkinkan siswa dapat mengembangkan potensi dirinya secara optimal. Koesoema (2007:235) mengemukakan perumpamaan bahwa sebuah sekolah tanpa kedisiplinan ibarat kincir tanpa air. Kincir tanpa air tentu akan berhenti berputar atau macet.

Guna membangun pengertian para siswa tentang keberadaan aturan disiplin digunakan istilah 'qanun'. Kata 'qanun' dipandang sebagai simbol aturan komando yang berlaku di lingkungan PM. 'Qanun' berupa aturan tidak tertulis yang dibacakan dan harus diingat baik-baik oleh siswa serta tidak boleh dilanggar. Keberadaan 'qanun' harus menjadi kesadaran aktif setiap siswa dalam melaksanakan aktivitas sehari-hari di lingkungan pondok. Itulah keunikan 'qanun' sebab pada umumnya tata tertib sekolah tertulis dan ditempel di dinding depan ruang kelas atau tempat lain yang strategis.

Di samping 'qanun' terdapat pula indeks lain yang mengisyaratkan konsep penegakan disiplin, yaitu metode 'jasus'. Dalam rangka menekan tingkat pelanggaran disiplin, PM menggunakan metode 'jasus'. 'Jasus' atau mata-mata merupakan hukuman tambahan bagi pelanggar ‘qanun'. Tugas ‘jasus’ adalah mencatat pelanggaran disiplin yang terjadi di sekitarnya. Model penegakan disiplin tersebut bertujuan mendidik para siswa agar berani berkata jujur atau benar tentang berbagai pelanggaran disiplin yang dilihatnya. Landasan metode jasus adalah hadist Nabi SAW, 'Katakanlah yang benar walaupun pahit'; "Qul al-haqq wa law kana murran". Sabda Rasul tersebut secara tersirat juga menunjukkan bahwa mengatakan sesuatu yang benar tidaklah selalu mudah, karena kebenaran yang kita ungkapkan dapat mengenai diri kita sendiri. Walaupun demikian, kejujuran akan membawa kebajikan.

\section{Konsep Kesungguhan dan Kerja Keras}

Konsep kesungguhan dan kerja keras ditandai dengan indeks (1) ketekunan siswa, dan (2) pemahaman nilai kesungguhan dan kerja keras.

Ketekunan siswa dalam belajar ditandai dengan banyaknya siswa yang membaca buku di perpustakaan dengan suasana yang tenang dan suara yang terdengar hanya halaman buku dibuka. Di samping faktor ketekunan siswa, kepada mereka selalu dianjurkan untuk mengamalkan 'man jadda wajada'. Potongan syair tersebut merupakan simbolisasi spirit yang besar dan pantang menyerah. Walaupun syair tersebut bermakna jelas, yakni 'siapa bersungguh-sungguh akan berhasil' namun terdapat indikasi bahwa praksis pemahaman terhadap konsep nilai kesungguhan tersebut melalui cara yang sangat unik. Semua siswa diminta menirukan dengan keras pengucapan potongan syair tersebut oleh guru. Proses tersebut dilakukan berulang-ulang dengan ucapan semakin keras sehingga memunculkan letupan spirit yang besar pada diri siswa. Dengan demikian yang diutamakan bukanlah pemahaman konsep nilai kesungguhan secara akal melainkan efek magis pada diri siswa saat syair tersebut dilafalkan. Karena itu terdapat pula simbol lain yang merujuk pada potongan syair tersebut, yakni 'mantera ajaib'.

\section{Konsep Kepemimpinan}

Ungkapan berupa moto 'siap memimpin dan dipimpin’ merupakan indeks konsep kepemimpinan dalam konteks pendidikan karakter di PM. Kiai, pemimpin pondok saat memberikan ucapan selamat kepada para siswa yang berhasil naik ke kelas enam mengatakan bahwa para siswa telah berhasil mempraktikkan 'moto siap memimpin dan dipimpin'. Hal itu membuktikan bahwa seluruh praksis pendidikan di PM ditujukan untuk menyiapkan para santrinya menjadi pemimpin. Namun, sebelum berhasil naik ke kelas tertinggi para siswa harus ikhlas dipimpin dan diarahkan oleh kakak seniornya ataupun guru.

Landasan praksis kepemimpinan dalam Islam adalah sabda Rasulullah SAW yang diriwayatkan oleh Abdullah bin Umar r.a.,

Rasulullah SAW telah bersabda, "Camkanlah bahwa kalian semua pemimpin dan akan dituntut (diminta pertanggungjawaban) tentang hal yang dipimpinnya.” (Syafe'i, 2000:234).

Hadist di atas mengisyaratkan maksud bahwa setiap orang adalah pemimpin dan akan diminta pertanggungjawaban atas apa yang dipimpinnya. Dalam kepemimpinan terkandung nilai tanggung jawab kare- 
na kedudukan pemimpin adalah amanah yang harus dilakukan sebaik-baiknya demi kebaikan bersama.

\section{Pengaturan Lingkungan Belajar}

Pengaturan lingkungan belajar di PM ditandai dengan indeks yang mengisyaratkan penyambutan pekan ujian dengan meriah berupa pemasangan berbagai poster, dan selebaran yang memacu semangat belajar di tempat-tempat strategis di lingkungan PM. Diselenggarakan pula upacara pembukaan (launching ceremony) pekan ujian layaknya sebuah kompetisi olahraga yang bergengsi. Ditutup pula dengan sebuah upacara pemberian ucapan selamat kepada para siswa yang telah berjuang dalam menghadapi ujian. Siswa menyambut pekan ujian dengan suka cita, tidak dengan rasa takut atau stress seperti yang sering terjadi saat ini. Dengan kondisi yang gempita tersebut setiap siswa terdorong menjadi rajin belajar. Tekun dan rajin belajar menjadi kultur keseharian para siswa di lingkungan PM.

Dalam rangka melindungi siswa dari pengaruh negatif informasi dari luar, PM melakukan seleksi terhadap informasi yang masuk. Dibentuk tim dari siswa senior yang ditugasi menyeleksi informasi yang masuk ke PM, misalnya dengan membatasi jumlah surat kabar yang boleh dibaca para siswa, menutup bagian-bagian tertentu yang dianggap dapat berpengaruh negatif terhadap perkembangan kepribadian siswa. Semua itu merupakan indeks bahwa PM menganut sistem tertutup atau sistem pendidikan 24 jam.

\section{Sumber Nilai Karakter}

Terdapat indeks yang mengisyaratkan bahwa sumber nilai-nilai karakter yang ditanamkan pada siswa di PM adalah Al Quran, Al Hadist, dan mahfuzhat (peribahasa Arab). Nilai-nilai kartakter yang bersumber dari Al Quran misalnya (1) nilai keikhlasan, (2) nilai ikhtiar/usaha, (3) nilai ketaqwaan (doa dan tawakal), (2) nilai kesabaran. Nilai-nilai karakter yang bersumber dari Al Hadist misalnya (1) nilai kepemimpinan, (2) nilai tanggung jawab, (3) nilai keindahan, (4) kejujuran, (5) keteladanan, (6) nilai suka belajar/menuntut ilmu. Nilai-nilai karakter yang bersumber dari mahfuzhat misalnya, nilai kesungguhan/kerja keras dengan potongan syair 'man jadda wajada', nilai kesabaran dengan potongan syair 'man shabara zhafira', nilai suka bertualang dari syair berbahasa Arab karya Imam Syafi'i dengan ungkapan/'orang pandai dan beradab tidak akan diam di kampung halaman/ tinggalkan negerimu dan merantaulah ke negeri orang' dst. Nilai-nilai karakter yang dikembangkan di lingkungan PM didominasi oleh nilai-nilai yang ber- sumber dari agama. Nilai-nilai karakter sesungguhnya dapat digali dari pandangan hidup atau ideologi bangsa, budaya, dan tujuan pendidikan nasional (Zubaedi, 2011:73).

\section{Aktivitas Penerapan Nilai-nilai Karakter oleh Tokoh Cerita}

\section{Praksis Kedisiplinan}

Praksis kedisiplinan ditandai dengan (1) ikon yang menggambarkan profil guru yang sangat keras menegakkan disiplin dan hapal dengan siswanya, (2) indeks yang mengisyaratkan pergantian kegiatan secara tertib dan disiplin, (3) kepatuhan siswa pada aturan, (4) kerasnya penegakan disiplin, (5) adanya kepastian hukuman bagi pelanggar 'qanun', (6) kedisiplinan dalam beribadah, (7) penanaman nilai kepedulian terhadap penegakan disiplin, (8) penerapan hukuman sebagai alat pendidikan.

Guru yang bernama Ustad Torik digambarkan sangat keras memegang aturan disiplin. Ustad Torik sangat hapal dengan catatan pelanggaran para siswanya, berkumis subur, dan berwajah horor. Dialah yang berwenang memberikan hukuman kepada siswa senior. Indeks kepatuhan siswa terhadap aturan disiplin ditandai adanya suasana pergantian kegiatan dengan isyarat bunyi lonceng dan pernyataan 'belum lagi gaungnya padam, semua penjuru sepi senyap, tidak ada orang satu pun'. Gambaran suasana tersebut menunjukkan betapa para siswa sangat patuh terhadap aturan disiplin yang ada. Kondisi lingkungan belajar yang tertib dan teratur merupakan jaminan berlangsungnya proses pendidikan yang baik.

Pembiasaan berlaku tertib dan disiplin tidak hanya dalam kegiatan belajar tetapi juga dalam kegiatan beribadah. Ungkapan ‘razia ngantuk’ misalnya, merupakan indeks penerapan kedisiplinan dalam kegiatan shalat berjamaah di masjid. Ungkapan tersebut mengisyaratkan perbuatan mengantuk merupakan larangan saat shalat berjamaah di masjid. Perbuatan mengantuk bahkan dianggap 'mencuri waktu tidur' . Perbuatan 'mencuri' adalah perbuatan dosa. Perilaku 'ngantuk' di masjid juga dianggap sebagai penyakit menular yang perlu diberantas. Hal tersebut terungkap dengan indeks 'wabah tidur massal'.

\section{Praksis Kesungguhan dalam Berusaha}

Praksis kesungguhan dalam berusaha dilaksanakan secara sistematis di PM. Praksis kesungguhan bertujuan untuk mendorong siswa meraih prestasi 
terbaiknya. Bohlin (1999:64-66) mengatakan bahwa terdapat enam cara yang dapat dilakukan guru untuk memotivasi siswa agar bersikap lebih baik. Keenam cara tersebut adalah (1) keteladanan, (2) penjelasan, (3) lingkungan yang kondusif, (4) memberi pengalaman belajar, (5) nasihat/peringatan, (6) dorongan meraih yang terbaik.

Tradisi kompetisi di PM merupakan indeks praksis kesungguhan dalam berusaha. Di samping 'Liga Madani', tradisi kompetisi sepak bola tahunan terdapat juga tradisi membuat foto kelas terbaik dan pementasan mutliseni bagi kelas VI (class six show). Selain tradisi kompetisi terdapat pula penugasan sesuai dengan bakat dan keahlian siswa misalnya, tantangan membuat koran harian dan koran instan yang meliput rangkaian kegiatan ulang tahun PM ke-70 dengan nama Kilas 70, tugas berpidato di depan tamu asing (student speaker). Dalam melaksanakan tugas-tugas tersebut di samping niat ikhlas siswa selalu mengamalkan mantera sakti 'man jadda wajada'. Tugas dan tantangan merupakan upaya guru untuk menumbuhkan kebiasaan siswa meraih yang terbaik (expectation of excellence).

Sistem ujian yang ketat dan pengaturan lingkungan yang sesuai juga merupakan indeks penanaman nilai kesungguhan dan kerja keras siswa untuk meraih prestasi terbaiknya. Kegigihan dan ketekunan para siswa dalam belajar ditunjukkan saat menjelang ujian. PM membentuk tim khusus dari siswa senior yang bertugas membantu adik-adik kelasnya. Aktivitas belajar seakan menjadi gerakan massal di tengah malam buta. Fasilitas ruang aula disiapkan dan listrik yang biasanya dimatikan sejak sore, dinyalakan sampai pagi. Pengaturan kegiatan diperlonggar, memberikan kesempatan belajar sebanyak-banyaknya kepada siswa untuk mempersiapkan ujian. Pengaturan lingkungan dan irama kegiatan keseharian menumbuhkan kegilaan para siswa untuk belajar yang ditandai dengan penggunaan ungkapan 'exam frenzy'.

\section{Praksis Kepemimpinan}

Siswa adalah calon generasi penerus. Format pendidikan karakter yang mampu mengembangkan nilai-nilai kepemimpinan dalam diri siswa diperlukan. Indeks praksis kepemimpinan meliputi: (1) pemberian tugas pengabdian secara bergilir sesuai senioritas siswa, (2) pemberian tugas bergilir menjadi imam shalat berjamaah, (3) pratik berpidato tiga kali seminggu.

Di PM latihan kepemimpinan telah dimulai sejak awal saat menjadi siswa baru, misalnya dengan adanya tugas bergilir menjadi imam shalat berjamaah di kelasnya masing-masing dan praktik berpidato dalam bahasa Indonesia, Inggris, dan Arab tiga kali dalam seminggu. Tradisi ‘penyerahan kekuasaan' dari siswa kelas VI kepada siswa kelas V merupakan indeks adanya pemberian tugas secara bergilir sesuai senioritas siswa. Tugas pengabdian kepada lembaga, misalnya ketua asrama, ketua tim disiplin, ketua penggerak bahasa, ketua redaktur majalah sekolah, dsb.

Simbolisasi praksis kepemimpinan di PM adalah penggunaan motto 'siap memimpin dan dipimpin'. Siswa yang berada pada tingkat awal harus 'manut' dibimbing oleh seniornya sedangkan siswa pada tingkat lanjut (senior) harus siap membimbing adik kelasnya dengan niat yang ikhlas. Keteladanan siswa senior adalah sangat penting. Di samping sebagai teladan, bukankah tugas utama seorang pemimpin adalah melayani kepentingan orang yang dipimpinnya. Firman Allah SWT dalam Al Quran: Rendahkanlah sikapmu terhadap pengikutmu dari kaum mukminin (Q.S. Asy-Syu'ara:215).

\section{Praksis Kebersamaan}

Untuk menerapkan nilai kebersamaan dalam belajar, PM membentuk kelompok-kelompok belajar guna memaksimalkan kerja sama saling bantu belajar di antara para siswa. Setiap kelompok mendapat jatah tempat di aula yang meja-kursinya telah diatur. Para guru/ustad berkeliling saat terjadi proses belajar dan siap memberikan penjelasan kalau ada pertanyaan. Cara ini dapat menumbuhkan semangat belajar yang tinggi. Siswa yang merasa lemah pada pelajaran tertentu dapat meminta bantuan pada temannya yang pandai, apalagi kegiatan tersebut juga dipandu para guru/ustad. Dalam situasi ini peran guru benar-benar sebagai fasilitator dalam belajar.

Pada konteks praksis pendidikan saat ini belajar secara kelompok antara yang pandai dan kurang pandai tidak terbentuk. Persaingan yang tidak sehat dan saling menjatuhkan dalam merebut posisi ranking kelas yang lebih baik adalah penyebabnya. Sistem ujian cenderung bersifat mengukur seberapa banyak penguasaan materi penting yang telah dipelajarinya. Dimensi praktis ilmu pengetahuan yang dikuasai siswa cenderung tereduksi oleh model soal-soal objektif. Demikian pula dimensi nilai pedagogis berupa berkembangnya kepribadian yang tahan uji dalam menghadapi berbagai persoalan nyata dalam keseharian. Karena itu, dipandang perlu reorientasi pendidikan ke arah pembentukan intelegensi praktis (practical intelligence) seperti disarankan oleh Koesoema (2007:276), yakni kemampuan menggunakan berba- 
gai pengetahuan yang dimiliki dalam situasi dan kondisi tertentu sehingga dapat melakukan tindakan yang bermakna bagi dirinya dan orang lain.

\section{Praksis Ketaqwaan}

Praksis ketaqwaan ditandai dengan penerapan nilai ketaqwaan dan keikhlasan yang terintegrasi ke dalam berbagai aktivitas pendidikan di PM. Sejalan dengan strategi PM yang menggunakan nilai-nilai agama sebagai landasan setiap aktivitas pendidikannya. Bentuk penerapan konsep tersebut, misalnya setiap melaksanakan kegiatan belajar, kiai selalu menganjurkan para siswa mengawalinya dengan niat ikhlas hanya karena Allah SWT. Guna memantapkan niat dan agar diberi kemudahan atau mendapat petunjuk, kiai selalu mengajak para siswa untuk berdoa bersama. Pelaksanaan ibadah shalat berjamaah secara rutin dan terjadwal baik dilakukan di masjid maupun di ruang kelas adalah merupakan implementasi penanaman nilai ketaqwaan kepada Allah SWT.

Dari pembahasan dapat disimpulkan bahwa praksis penerapan nilai-nilai karakter dalam novel N5M ditujukan untuk membentuk pribadi siswa yang berdisiplin tinggi, suka bekerja keras dan sungguhsungguh berusaha untuk meraih yang terbaik, berjiwa pemimpin, mampu bekerja sama dalam tim dan menghargai perbedaan, serta taqwa kepada Allah SWT.

\section{Aktivitas Refleksi Tokoh Cerita terhadap Nilai-nilai Karakter}

\section{Kesadaran Tokoh akan Manfaat Praksis Ibadah}

Setelah tiga tahun menempuh pendidikan di PM barulah tokoh aku menyadari bahwa ucapan kiai ' $k a$ mi ikhlas mendidik, dan ikhlaskan niat kalian untuk dididik' bukan sekedar basa-basi tetapi merupakan kenyataan yang dialami tokoh dalam keseharian. Sikap ikhlas dalam proses pendidikan dipandang sebagai pakta suci hubungan guru-siswa. Keikhlasan juga dipandang sebagai prinsip yang sakti dan manjur. Dalam berbagai kegiatan baik senang dan susah selalu dihibur dengan ucapan 'ikhlaskan ya akhi ...'. Ucapan tersebut mampu membuat hati menjadi 'plong' dan badan terasa segar kembali. Hal tersebut merupakan indeks yang mengisyaratkan tumbuhnya kesadaran tokoh akan kekuatan sikap ikhlas dalam aktivitas pendidikan sehari-sehari.

Keteladanan dalam keikhlasan dipertontonkan oleh para guru/ustad di PM dalam keseharian. Mereka tidak menerima gaji dan tinggal di asrama dengan fasilitas yang cukup. Dengan tidak adanya ekspektasi gaji semua aktivitas pendidikan dilakukan dengan upaya maksimal dengan mutu terbaik. Niat mereka mengajar semata-mata karena ibadah kepada Allah SWT. Semua itu merupakan indeks implementasi ibadah dalam proses pendidikan. Keteladanan guru/ustad membuat para siswa ikhlas untuk dididik dan bersikap tawadhuk (manut) kepada para gurunya.

Penyambutan pekan ujian dengan meriah menumbuhkan kesadaran tokoh cerita bahwa sekalikali orang hendaknya tidak takut menghadapi ujian. Ujian akan selalu datang dalam kehidupan seseorang dalam berbagai rupa. Hal tersebut merupakan indeks kritik terhadap kondisi saat ini yang menunjukkan bahwa banyak siswa atau orang tua mendadak mengalami stres jika ujian sekolah akan dilaksanakan. Untuk mengatasi tekanan ujian tersebut tokoh mengamalkan nilai-nilai ibadah dalam aktivitas belajarnya. Ketatnya ujian akhir atau 'imtihan nihai' menyadarkan tokoh bahwa keberhasilan seseorang dalam mengatasi ujian ternyata tidak ditentukan oleh banyaknya ilmu yang dimiliki seseorang tetapi lebih ditentukan oleh seberapa tahan seseorang terhadap tekanan kebosanan psikologis dan kelelahan fisik, untuk itu diperlukan sikap sabar. Perasaan stress dapat diatasi dengan berusaha sungguh-sungguh melebihi rata-rata orang lain, kemudian berdoa dan bertawakal.

\section{Kesadaran Tokoh akan Manfaat Praksis Kepemimpinan}

Tumbuhnya kesadaran tokoh terhadap rasa percaya diri tampil di depan umum akibat praksis kepemimpinan yang dijalaninya di PM. Tokoh aku menyadari telah terjadi perubahan dalam dirinya. Jika dahulu ia sangat pemalu apalagi harus tampil berpidato di depan umum, kini ia mampu tampil di depan umum dengan penuh percaya diri. Dengan latihan pidato tiga kali seminggu, latihan menjadi imam shalat, kegiatan pramuka pelan-pelan dapat menumbuhkan rasa percaya diri tokoh untuk tampil di depan umum, walaupun pada mulanya ia hanya meniru gaya kakakkakak seniornya dalam berpidato namun lama kelamaan kepura-puraan tersebut menjadi kenyataan diri yang sesungguhnya.

PM memberikan kesempatan yang seluas-luasnya kepada para siswa untuk berlatih menjadi pemimpin atau yang dipimpin. Tugas-tugas seperti ketua kamar, ketua asrama, ketua kelas, ketua klub olahraga, dan banyak lagi jabatan lainnya setiap tahun bergantian. Hal ini merupakan indeks berlangsungnya praksis kepemimpinan di PM. Setiap siswa selama 
menempuh pendidikan di PM setidaknya pernah berpengalaman menjadi seorang pemimpin.

\section{Kesadaran Tokoh Pentingnya Mempunyai Cita-cita/Impian}

Bercita-cita tinggi disertai niat kuat untuk mewujudkannya telah menyadarkan tokoh adanya jalan menuju sukses yang diinginkan. Lingkungan belajar yang kondusif ditandai dengan keteladanan guru yang hebat dan ikhlas dalam menjalankan tugasnya, adanya pergaulan yang memungkinkan terjadinya saling berbagi cerita dan saling memberi semangat telah menumbuhkan tekad kuat tokoh dalam mewujudkan cita-citanya, yakni melanjutkan belajar ke luar negeri. Walaupun cita-citanya mungkin sangat sulit diraih tetapi pengalaman telah mengajarkannya bahwa spirit 'man jadda wajada' disertai usaha keras dan pantang menyerah dapat memberi jalan meraih apa yang diinginkannya.

Cita-cita atau tujuan hidup seseorang akan mengarahkan semua pikiran dan tindakannya pada satu titik kemungkinan yang dapat diraihnya. Tujuan hidup seseorang adalah apa yang ia niatkan untuk dicapai. Misi hidup seseorang adalah misi yang ia ciptakan sendiri. Hidup seseorang adalah hidup yang ia ciptakan sendiri tidak seorang pun berhak menghakiminya (Byrne, 2007:207). Pernyataan tersebut mengisyaratkan setiap orang memiliki kebebasan dalam menetapkan impian yang akan diraihnya di kemudian hari. Dalam pandangan Islam bahwa apa yang akan didapat seseorang dari segala amalan yang dilakukannya bergantung pada niatnya.

Ungkapan 'dulu kami melukis langit dan membebaskan imajinasi itu membubung tinggi’ merupakan indeks kebebasan para siswa PM menggantung asanya di langit senja di bawah menara masjid yang tinggi menjulang. Setelah mengerahkan segala ikhtiar dan menggenapkan dengan doa, mereka dapat meraih impian masing-masing. Keenam siswa PM tersebut berhasil berada di lima negara, yakni Arab, Inggris, Mesir, Amerika Serikat, dan Indonesia seperti yang diimpikannya. Karena itu, judul novel ini adalah 'Negeri Lima Menara' yang sesungguhnya merupakan simbolisasi cita-cita keenam siswa tersebut. Nama kelompok siswa tersebut adalah 'Shahibul Menara' yang berarti ‘yang mempunyai menara' atau mengiaskan maksud kelompok siswa yang bercita-cita tinggi. Keenam siswa PM tersebut dapat meraih impiannya setelah melaksanakan praksis ibadah, yakni ikhtiar dan doa. Mereka yakin bahwa Allah SWT Maha mendengar setiap doa dan akan mengabulkannya.

\section{Kesadaran Tokoh akan Tumbuhnya Kedewasaan}

Proses pendidikan merupakan jalan bagi seorang siswa menuju kedewasaan. Konsep kedewasaan merujuk pada kondisi mental seseorang yang matang dalam berpikir dan bijak dalam mengambil keputusan. Proses belajar yang dialami tokoh di PM direfleksinya sebagai pengalaman hidup dengan akselerasi yang luar biasa. Pernyataan 'kita seperti sedang belajar silat di kuil Shaolin' merupakan indeks dari ketatnya proses belajar tersebut. Karena itu, saat tokoh berhasil naik ke kelas enam ia merasa bangga atas keberhasilannya lolos dari seleksi ketat PM dan merasa memiliki kemampuan lebih dibanding adik-adik kelasnya.

Kemampuan lebih tokoh tersebut diungkapkan dengan kiasan 'seperti seekor burung yang melihat daratan di bawahnya' sedangkan saat di kelas satu diungkapkan dengan kiasan 'seperti katak kecil yang terkaget-kaget melihat gemuruh di PM'. Kiasan pertama merupakan indeks mulai tumbuhnya kedewasaan pada diri tokoh. Kiasan mengandung maksud bahwa tokoh dapat memahami dengan baik apa yang sedang terjadi di sekitarnya dan mengetahui mengapa hal itu terjadi. Tokoh dapat mengambil keputusan secara bijak dan menentukan sikap tepat terhadap segala peristiwa yang dialaminya. Kiasan kedua merupakan indeks kurangnya pengetahuan yang dimiliki dan tidak tahu bagaimana harus bersikap terhadap peristiwa yang terjadi di sekitarnya.

\section{Kesadaran Tokoh akan Pentingnya Hidup dalam Suasana Pergaulan yang Baik}

Lingkungan belajar hakikatnya adalah miniatur sebuah masyarakat lengkap dengan segala aturan, tradisi atau kebiasaan baik yang belaku di dalamnya. Hasil sebuah proses belajar tidak sekadar terkuasainya segala pengetahuan dan kecakapan yang penting bagi kehidupan siswa tetapi juga terbentuknya pribadi siswa menjadi seorang yang siap hidup berdampingan secara damai dengan orang lain di masyarakatnya. Kesadaran tokoh cerita tentang pentingnya hidup dalam suasana saling membantu dan menghargai satu sama lain ditandai dengan indeks yang mengisyaratkan (1) tumbuhnya sikap toleransi atau menghormati yang lebih tua dalam pergaulan, (2) kesadaran akan manfaat suasana pergaulan yang saling bantu dan memberi semangat, (3) kesadaran tokoh atas peran shalat berjamaah sebagai alat pemersatu berbagai kelompok masyarakat. 
Suasana belajar ditandai dengan hubungan pergaulan yang baik antar teman, atau dengan guru, misal saling memberi semangat atau membantu kawan yang kurang dalam hal belajar dan tidak memperolokolok atau menertawakan kekurangan kawan tentu dapat memacu semangat belajar setiap siswa untuk meraih yang terbaik. Pernyataan 'rasanya mudah frustasi kalau kami tidak selalu mendapatkan encouragement dari guru, teman, dan kakak kelas' merupakan indeks suasana belajar yang baik yang memungkinkan setiap siswa terus berusaha dan tidak takut salah dalam belajar apalagi dalam mempraktikkan bahasa asing dalam keseharian.

\section{Kesadaran Tokoh akan Kewibawaan dan Ketinggian Ilmu yang Dimiliki PM}

Pengalaman tokoh selama menempuh pendidikan di PM memberikan kesadaran baru bahwa PM merupakan lembaga yang sangat berwibawa dan mampu membekali siswanya dengan ilmu yang bermanfaat baik dunia maupun akhirat. Kesadaran tokoh ditandai dengan ikon yang menggambarkan kemegahan dan kewibawaan PM sebagai lembaga pendidikan, dan simbol kewibawaan dan ketinggian ilmu PM.

Kesan pertama tokoh terhadap kompleks bangunan di PM diungkapkan secara ikonis sebagai memiliki pemandangan lapangan rumput hijau yang luas, di sekitarnya tampak pohon-pohon hijau rindang dan pucuk-pucuk kelapa yang mencuat dan menarinari dihembus angin, memiliki kompleks gedung bertingkat yang megah. Sebuah kubah besar berwarna gading mendominasi langit, didampingi sebuah menara yang tinggi menjulang. Hal tersebut mengiaskan maksud betapa PM merupakan lembaga pendidikan yang megah dan berwibawa. Komplek PM diungkapkan secara simbolik dengan 'kampung di atas awan'. Ungkapan tersebut mengiaskan maksud sangat tinggi ilmu yang dipelajari para siswa di PM.

Disimpulkan bahwa praksis ibadah yang dijalani tokoh telah memberikan kesadaran baru terbentuknya kepribadian tangguh dan mendorongnya untuk terus belajar sepanjang hidupnya. Proses belajar yang keras dengan disiplin tinggi dan praksis kepemimpinan yang dijalani menumbuhkan kesadaran tokoh terhadap kedewasaan dirinya dan sikap percaya diri dalam pergaulan pada level manapun. Keberhasilan tokoh meraih impiannya mengingatkan pada pengalaman manisnya bersama kawan-kawan baiknya saat menempuh pendidikan di PM yang penuh senda gurau dan doa. Kekaguman tokoh pada kewibawaan dan ketinggian ilmu di PM merupakan ungkapan rasa syukur kepada Allah SWT yang telah memberi jalan dan mengabulkan doa-doanya.

\section{SIMPULANDAN SARAN}

\section{Simpulan}

Makna semiotik aktivitas pemahaman tokoh cerita novel N5M terhadap nilai-nilai karakter mencakup tujuh hal tentang praksis pendidikan karakter, yakni (1) pendekatan ibadah, (2) metode dan strategi pendidikan karakter, (3) konsep kedisiplinan, (4) konsep kesungguhan dalam berusaha, (5) konsep kepemimpinan, (6) pengaturan lingkungan belajar, dan (7) sumber nilai karakter.

Makna semiotik aktivitas penerapan nilai-nilai karakter oleh tokoh cerita novel N5M mencakup lima strategi praksis pendidikan karakter, yakni (1) praksis kedisiplinan, (2) praksis kesungguhan dalam berusaha, (3) praksis kepemimpinan, (4) praksis kebersamaan, dan (5) praksis ketaqwaan.

Makna semiotik aktivitas refleksi tokoh cerita nvel N5M terhadap penerapan nilai-nilai karakter mencakup enam kesadaran tentang nilai karakter, yakni (1) manfaat praksis ibadah, (2) manfaat praksis kepemimpinan, (3) pentingnya mempunyai cita-cita, (4) tumbuhnya kedewasaan, (5) pentingnya suasana pergaulan yang baik, (6) kewibawaan dan ketinggian ilmu PM.

Model praksis pendidikan karakter dalam novel N5M menggunakan pendekatan ibadah yang ditandai dengan (1) konsep menuntut ilmu dalam Islam, (2) konsep keutamaan menuntut ilmu, (3) konsep 'rahmatan lil alamin', (4) setiap aktivitas 'belajar' merupakan prosesi ibadah, yakni dimulai dengan niat, usaha sungguh-sungguh, berdoa, dan tawakal, (5) konsep kepemimpinan dalam Islam.

Strategi yang ditempuh PM untuk membentuk lulusannya agar menjadi manusia mandiri yang tangguh adalah (1) memadukan ilmu umum dan ilmu agama, (2) menggunakan 'mantera' penumbuh semangat yakni potongan syair Arab 'man jadda wajada'; siapa bersungguh-sungguh akan berhasil', (3) memberikan pelajaran 'mahfudzat', yakni peribahasa Arab yang sarat dengan nilai-nilai karakter, (4) menciptakan kultur sekolah yang baik, (5) melakukan kontrol ketat terhadap informasi yang masuk ke lingkungan pondok, (6) melatih santri mahir berpidato dalam bahasa Indonesia, Inggris, dan Arab. Adapun metode yang digunakan dalam praksis pendidikan karakter 
di PM adalah (1) metode dakwah, (2) metode tasji'/ motivasi, (3) metode penjelasan, (4) metode kompetisi, (5) metode penugasan, (6) metode keteladanan, (7) metode kedisiplinan, dan (8) metode kebersamaan.

\section{Saran}

Berdasarkan simpulan tersebut disarankan (1) bagi guru Bahasa dan Sastra Indonesia, novel N5M dapat dijadikan bahan ajar yang sarat dengan nilainilai karakter, (2) bagi calon guru Bahasa dan Sastra Indonesia, model praksis pendidikan karakter dalam novel N5M dapat dijadikan bahan kajian di perkuliahan, (3) bagi peneliti selanjutnya, penelitian ini dapat dikembangkan pada novel sejenis dengan latar cerita yang berbeda guna memperkaya model praksis pendidikan karakter yang ada, (4) bagi sekolah, model praksis pendidikan karakter dalam novel N5M dapat dijadikan sumber inspirasi pengelolaan kelembagaan yang berbasis nilai-nilai karakter.

\section{DAFTARRUJUKAN}

Aminuddin. 2002. Metasemiotik sebagai Dasar Teks Sastra. Dalam Masinambow, E.K.M., dan Hidayat, Rahayu, S. (ed.), Semiotik, Kumpulan Makalah Seminar (hlm. 41-54). Jakarta: Pusat Penelitian Kemasyarakatan dan Budaya, Lemlit UI.
Bohlin, K.E. 1999. Building Character in Schools, Resources Guide. San Francisco: John Wiley \& Sons, Inc.

Byrne, R. 2007. The Secret, Rahasia. Jakarta: PT Gramedia Pustaka Utama.

Chandler, D. 2007. The Basic Semiotics. London and New York: Routledge

Danesi, M. \& Perron. 1999. Analyzing Cultures. Bloomington/Indianapolis: Indiana University Press.

Koesoema, D. 2007. Pendidikan Karakter, Strategi Mendidik Anak di Zaman Global. Jakarta: Grasindo.

Freire, P., Danandjaya, L., dkk. 1985. Pendidikan Kaum Tertindas. Jakarta: LP3ES.

Hasbullah. 1999. Sejarah Pendidikan Islam di Indonesia: Lintasan Sejarah Pertumbuhan dan Perkembangan. Jakarta: PT Raja Grafindo Persada.

Hoed, B.H. 2011. Semiotik dan Dinamika Sosial Budaya. Jakarta: Komunitas Bambu.

Lathief, S.I. 2010. Sastra: Eksistensialisme-Mistisisme Religius. Lamongan: Pustaka Pujangga.

Rafiek, M., 2010. Teori Sastra, Kajian Teori dan Praktik. Bandung: PT Refika Aditama.

Syafe'i, R. 2000. Al-Hadis (Aqidah, Akhlaq, Sosial, dan Hukum). Bandung: CV Pustaka Setia.

Teeuw, A. 1984. Sastra dan Ilmu Sastra. Jakarta: Pustaka Jaya.

Zubaedi. 2011. Desain Pendidikan Karakter: Konsepsi dan Aplikasinya dalam Lembaga Pendidikan. Jakarta: Kencana Prenada Media Group. 